НАУКОВИЙ ВІСНИК

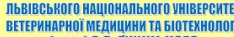

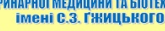
Scientific messenger of L L wiv National University of
Veterinary Medicine and Biotechnologies

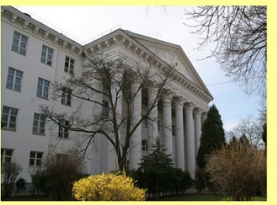

СЕРІЯ “ЕКОНОМІЧН НАУКІ

Том 23 № 98

202
Науковий вісник Дьвівського національного університету ветеринарної медицини та біотехнологій імені С.3. Гжицького. Серія: Економічні науки

\author{
Scientific Messenger of Lviv National University \\ of Veterinary Medicine and Biotechnologies. \\ Series: Economical Sciences
}

ISSN 2519-2701 print

UDC 314:711.13:316.3:33

\title{
Problems of socio-economic development and ways to improve it for rural areas in Lviv region
}

\author{
R. Grabovsky ${ }^{1}$, M. Dorosh-Kizym ${ }^{1}$, M. Dorosh ${ }^{2}$, R. Dudyak ${ }^{3}$ \\ ${ }^{1}$ Stepan Gzhytskyi National University of Veterinary Medicine and Biotechnologies Lviv, Lviv, Ukraine \\ ${ }^{2}$ Lviv University of Business and Law, Lviv, Ukraine \\ ${ }^{3}$ Old Polish University, Kielce, Poland
}

Article info

Received 14.10.2020

Received in revised form 29.11.2020

Accepted 01.12.2020

Stepan Gzhytskyi National University of Veterinary Medicine and Biotechnologies Lviv,

Pekarska Str. 50, Lviv, 79010

Ukraine.

Tel.: +038-067-67-548-89:

E-mail:romansg@ukr.net

Lviv University of

Business and Law,

Kulparkivska Str., 99, Lviv,

79021, Ukraine.

Old Polish University, Kielce, Poland
Grabovsky, R., Dorosh-Kizym, M., Dorosh, M., \& Dudyak, R. (2021). Problems of socio-economic development and ways to improve it for rural areas in Lviv region. Scientific Messenger of Lviv National University of Veterinary Medicine and Biotechnologies. Series: Economical Sciences, 23 (98), 52-56. doi: $10.32718 /$ nvlvet-e9808

For a long time the issue of socio-economic development of rural areas, which have their characteristics, has not lost its relevance but also is united by common unsolvable problems that restrict their development in Ukraine. The socio-economic decline of the village can not only reduce economic performance in agriculture but will also have a negative impact on depopulation, environmental deterioration, reduce the efficiency of natural resources, as well as the destruction of the cultural environment. The article presents the results of a study of the socio-economic situation in rural areas, analysis of economic and environmental indicators of the use of agricultural resources in the production of crop and livestock products in villages by different categories of producers. The publication provides information on the profitability of production in agricultural formations from 2010 to 2020. It has been established that the reason for the lack of growth in production in households is the irrational and economically unjustified use of resources and the lack of modern technologies. The publication also reveals the trends in the production output of livestock and crop production by different categories of producers. The indicators of production profitability were analyzed by agricultural enterprises during 2010-2020. The ways and means of improving the situation of using the natural resources by private agricultural enterprises, increasing economic indicators in the rural sector, and increasing production in agricultural enterprises are given. The results of the previous research show the possibilities and prospects for the implementation of the economic potential of rural areas based on the efficient and economically structured governance on the given territories. In addition, in modern realities, there may be an inflow to the mainstream of the investment climate due to the process of decentralization of the local government, receiving investment in the community, and, the increasing of the economy as a result. The research has shown that the development of social and economic infrastructure depends on investment activity.

Key words: rural areas, socio-economic development, economic efficiency, profitability, diversification.

\section{Проблеми соціально-економічного розвитку та шляхи його покращення для сільських територій у Львівській області}

\author{
Р. С. Грабовський ${ }^{1}$, М. М. Дорош-Кізим ${ }^{1}$, М. М. Дорош ${ }^{2}$, Р. П. Дудяк ${ }^{3}$ \\ ${ }^{1}$ Львівський національний університет ветеринарної медиични та біотехнологій імені С. 3. Гэницького, м. Львів, \\ Україна \\ ${ }^{2}$ Львівський університет бізнесу та права, м. Львів, Украӥна \\ ${ }^{3}$ Старопольська вища школа, м. Кельце, Польщча
}


Тривалий час в Украӥні не втрачає актуальності проблематика соціально-економічного розвитку сільських територій, які мають свої особливості, але також об'єднані спільними невирішними питаннями, які гальмують їх розвиток. Соціально-економічний занепад села може привезти не лише до зниження економічних показників в аграрній сфері, але й матиме свій негативний вплив на процеси депопуляції населення, погіршення екологічної ситуації, зменшення ефективності використання природніх ресурсів, а також на знищення культурного середовища. У статті представлено результати дослідження сочіально-економічної ситуацї у сільській місцевості, аналіз економічних та екологічних показників використанням сільськогосподарських ресурсів під час виробництва рослинницької та тваринницької продукції на сільських територіях різними категоріями виробників. Встановлено, щзо причиною відсутності росту виробництва продукиії у господарствах населення є нераціональне $і$ економічно не обтрунтоване використання ресурсів, відсутність сучасних технологій. Виявлено тенденції у зміні обсягів виробництва тваринницької та рослинницької продукції різними категоріями виробників. Проаналізовано показники рентабельності виробництва продукції сільськогосподарськими підприємствами Львівської області протягом 2010 року та 2020 року. Наведено шляхи та способи удосконалення ситуації із використанням природних ресурсів особистими господарствами населення та сільськогосподарськими підприємствами, підвищення економічних показників в агарній сфері та збільшення виробництва у сільськогосподарських підприємствах. Результати проведеного дослідження свідчать про можливості і перспективи реалізачї економічного потенціалу сільських територій на основі ефективного те економічно обтрунтованого господарювання на даних територіях. До иього слід додати, щзо у сучасних реаліях, у контексті процесу децентралізації місиеві громади мають вплив на створення інвестиційного клімату, залучення іноземних та вітчизняних інвесторів за участі місчевих органів управління та жителів, і як наслідок активізачії економічного середовища у сільському населеному пункті. Як показали результати досліджень, саме від активізації інвестиційної діяльності залежить розвиток соиіально-економічної інфраструктури.

Ключові слова: сільські території, сочіально-економічний розвиток, економічна ефективність господарювання, рентабельність, диверсифікація.

\section{Вступ}

За роки Незалежності в Україні відбулись суттєві зміни у сільських територіях, які історично завжди відігравали велике значення для держави. На цих територіях проживає близько третини населення, яке постійно скорочується, створюється значна частина національного продукту, який забезпечує продовольчу безпеку та розширює можливості експорту вітчизняної продукції, за останні роки більшого поширення набувають такі несільськогосподарські види бізнесу як сільський туризм.

Вище згадані чинники надають вивченню перспектив розвитку сільських територій особливо великого значення, мають велику вагу для вирішення соціально-економічних, демографічних, екологічних проблем і надають цій тематиці пріоритету у дослідженнях вітчизняних науковців.

Аналізу проблем соціально-економічного розвитку сільських територій приділяла увагу значна кількість вітчизняних економістів серед яких: Саблук П. Т. (Sabluk, 2005), В.В.Борщевський, Х. М. Притула, В. С. Крупін, І. М. Куліш (Borshchevskyi et al., 2011), Бойко В. В., Васильців Т. Г., Волошин В. І., Іляш О. І., Лупак Р. Л. (Boiko et al., 2016), Талавиря М.П., Горай А.О. (Talavyria \& Horai, 2018), Хомюк Н. Л., Павліха Н. В. (Khomiuk \& Pavlikha, 2019), С. I. Белей (Belei, 2021) та багато інших.

Зважаючи на значну увагу вітчизняних економістів-аграрників до тематики розвитку сільских територій слід зазначити, що, актуальним є вивчення пов'язані із особливостями перспектив розвитку територій в умових адміністративної реформи, зростанням еміграційних потоків між Україною і державами СС, викликами пов'язаними із пандемією Covid-19, загостренням екологічної ситуації, а також можливостями, які відкриваютьсяу зв'язку з економічною інтеграцією з $\mathrm{CC}$.

Розвиток сільських територій є одним із найпріоритетніших завдань державної ваги, оскільки від його вирішення залежить на якому рівні і з яким економічним ефектом буде використовуватись потенціал тери- торії, яким чином буде покращуватись соціальна ситуація на селі, вирішуватись проблема зайнятості, яким чином буде розвиватись малий і середній бізнес, чи будуть забезпечені умови ресурсоощадного використання ПРП території, як будуть напрацьовуватись і втілюватись у життя локальні програми розвитку де буде враховано особливості тої чи іншої території. До особливостей території належать не лише природно кліматичні умови, чи особливості рельєфу території, але і інвестиційна привабливість 3 огляду на перспективи використання туристичного потенціалу, вирощування рослинницьких культур та ведення тваринництва із врахуванням особливостей території. Дослідження специфіки сільських територій дозволяє розробити сценарій розвитку подій чи досягнення цілей, бізнес-план, прогнозні показники в умовах існуючих економічних, політичних, демографічних та інших чинників.

Мета та завдання дослідження. Метою дослідження $є$ аналіз сучасної соціально-економічної ситуації на сільських територіях та пошук шляхів покращення існуючої ситуації. Розкриття мети дослідження грунтується на досягненні поставлених завдань, а саме: вивченні актуальних проблем розвитку сільських територій, соціально-демографічної ситуації, державного впливу на розвиток сільських територій, аналіз можливих шляхів підвищення прискорення територій з урахуванням їх економічної, географічної, демографічної специфік.

\section{Матеріал і методи досліджень}

Основу методології дослідження складають загальнонаукові економічні методи, зокрема - монографічний метод, при комплексному вивчені стану виробництва продукції сільського господарства у Львівській області; методи аналізу та синтезу при дослідженні обсягів виробництва рослинницької та тваринницької галузей; методи функціонального та емпіричного аналізу у дослідженнях перспектив соціально-економічного розвитку сільських територій. 


\section{Результати та їх обговорення}

Складна соціально-економічна ситуація у сільських територіях тривалий час не змінюється і перспективи іiі покращення підлягають сумніву, оскільки процеси їх насамперед економічного занепаду дедалі більше нагадують незворотній процес. Не вирішення проблеми відродження сільських територій у недалекому майбутньому може призвести до економічної, демографічної, культурної, духовної деградації села. У наслідок проведення реформування аграрного сектора у 90-тих роках селяни отримали у володіння земельний та майновий ресурси. Проте замість колективних і державних аграрних утворень не було створено ефективно діючі приватні господарські структури. Як наслідок у сільському господарстві відбувались постійне скорочення виробництва, особливо тваринницької продукції, не використовується або нераціонально використовується земельний ресурс, присутня значна трудова міграція тощо.

У такій ситуації для сучасних сільських територій постала низка питань, які потрібно вирішити, а саме: підвищення економічного та екологічного рівнів використання природних ресурсів, відновлення соціальної а також комунальної інфраструктур, покращення демографічної ситуації, стимулювання інвестиційної активності і стимулювання розвитку підприємництва. Вирішення цих завдань можливе у поєднанні стимулюючої державної політики, місцевих державних органів управління та іноземних інвесторів, а також за ініціативи місцевого населення. Підвищення економічної ефективності використання ресурсів провідне завдання вирішення якого матиме позитивний вплив на соціально-економічну ситуацію в селі.

\section{Таблиця 1}

Продукція сільського господарства у Львівській області (у постійних цінах, млн.грн)*

\begin{tabular}{|c|c|c|c|c|c|c|c|c|c|c|c|c|}
\hline \multirow{3}{*}{ Показники } & \multicolumn{11}{|c|}{ РОКИ } & \multirow{2}{*}{$\begin{array}{c}2020 \text { у } \\
\% \text { до } \\
2010 \\
\end{array}$} \\
\hline & 2010 & 2011 & 2012 & 2013 & 2014 & 2015 & 2016 & 2017 & 2018 & 2019 & 2020 & \\
\hline & \multicolumn{12}{|c|}{ Господарства усіх категорій } \\
\hline Продукція с.-г., млн. грн & 16563 & 18855 & 19686 & 19763 & 20869 & 20237 & 20741 & 22029 & 22819 & 23004 & 24007 & 145 \\
\hline Продукція рослинн., млн. грн & 9348 & 11885 & 12611 & 12435 & 13702 & 13199 & 13861 & 14927 & 15522 & 15968 & 16938 & 181 \\
\hline \multirow[t]{2}{*}{ Продукція тваринн., млн. грн } & 7216 & 6969 & 7075 & 7328 & 7167 & 7039 & 6880 & 7102 & 7296 & 7037 & 7069 & 98 \\
\hline & \multicolumn{12}{|c|}{ Сільськогосподарські підприємства } \\
\hline Продукція с.-г., млн. грн & 5096 & 6184 & 7182 & 7844 & 8695 & 8269 & 8968 & 10201 & 11103 & 11063 & 11872 & 233 \\
\hline $\begin{array}{l}\text { Продукція с.-г., у \% до по- } \\
\text { переднього року }\end{array}$ & & 121 & 116 & 109 & 111 & 95 & 108 & 114 & 109 & 100 & 107 & \\
\hline Продукція рослинн., млн. грн & 3319 & 4360 & 5205 & 5648 & 6608 & 6233 & 6859 & 7800 & 8405 & 8481 & 9115 & 275 \\
\hline \multirow[t]{2}{*}{ Продукція тваринн., млн. грн } & 1777 & 1823 & 1977 & 2197 & 2086 & 2037 & 2109 & 2401 & 2698 & 2583 & 2757 & 155 \\
\hline & \multicolumn{12}{|c|}{ Господарства населення } \\
\hline Продукція с.-г., млн. грн & 11468 & 12671 & 12503 & 11919 & 12174 & 11968 & 11773 & 11829 & 11716 & 11941 & 12135 & 106 \\
\hline $\begin{array}{l}\text { Продукція с.-г., у \% до по- } \\
\text { переднього року }\end{array}$ & & 110 & 99 & 95 & 102 & 98 & 98 & 100 & 99 & 102 & 102 & - \\
\hline Продукція рослинн., млн. грн & 6029 & 7525 & 7406 & 6787 & 7094 & 6966 & 7002 & 7127 & 7117 & 7487 & 7823 & 130 \\
\hline Продукція тваринн., млн. грн & 5439 & 5146 & 5097 & 5132 & 5080 & 5002 & 4772 & 4702 & 4599 & 4454 & 4313 & 79 \\
\hline
\end{tabular}

Згідно інформації представленої у таблиці 1 можна зробити висновок про відсутність росту виробництва продукції сільського господарства в ОСГ. Зокрема незначний і нестабільний ріст продукції рослинництва та незначне скорочення виробництва продукції тваринництва. Натомість можемо відзначити подвоєння виробництва продукції сільського господарства в агроформуваннях в основному за рахунок рослинницької галузі та незначний ріст у тваринництві.

3 цього можна зробити висновок про неефективність використання наявних ресурсів ОСГ. На нашу думку, цю ситуацію можна виправити за рахунок об'єднання ОСГ в кооперативи, передачі земельних ресурсів в користування агроформуванням, або диверсифікації у напрямку розвитку альтернативних видів бізнесу, зокрема сільського туризму. Неефективність використання ресурсів, звуження ринку праці у сільській місцевості призводить до катастрофічного скорочення чисельності працездатного населення за ра- хунок трудової міграції, зниження народжуваності. За період незалежності чисельність міського населення області скоротилась на 7,3 \%, а сільського на 12,4 \%. До цього слід додати значний відтік працездатного населення із села, який може сягати більше 50 \% жителів населеного пункту. У сукупності із старінням населення села трудовий потенціал вичерпується швидкими темпами.

Нарощування обсягів виробництва рослинницької галузі i високі показники рентабельності були пов'язані насамперед із сприятливою кон'юнктурою, модернізацією технологій, підвищенням урожайності, використанням ефекту масштабу та іншими чинниками. У тваринництві навпаки спостерігається нестабільність економічних показників прибутковості. Насамперед це стосується виробництва м'яса. Збитковість даної галузі призводить до скорочення поголів'я, зростання імпорту (таблиця 2). 
Таблиця 2

Рівень рентабельності виробництва основних видів продукції рослинництва та тваринництва у Львівській області у підприємствах, \% *

\begin{tabular}{|c|c|c|c|c|c|c|c|c|c|c|c|c|}
\hline & \multicolumn{11}{|c|}{ Роки } & \multirow{2}{*}{$\begin{array}{l}2020 \text { до } \\
2010, \\
\text { різниця }\end{array}$} \\
\hline & 2010 & 2011 & 2012 & 2013 & 2014 & 2015 & 2016 & 2017 & 2018 & 2019 & 2020 & \\
\hline Культури зернові та зернобобові & 4,5 & 8,3 & 4,3 & $-10,5$ & 15,9 & 25,3 & 11,3 & 13,6 & 17,5 & 0,5 & 12 & 7,5 \\
\hline Буряк цукровий фабричний & 56 & 29,2 & -3 & 0,2 & 7,8 & 44 & 61,4 & 11,9 & 8,1 & 0,1 & 6,6 & $-49,4$ \\
\hline Соняшник & 5 & 7,4 & 0,8 & 4,9 & 20,4 & 22,8 & 51,9 & 23,1 & 12,4 & 16,3 & 25,9 & 20,9 \\
\hline Соя & 2,5 & -16 & $-0,7$ & $-13,7$ & $-2,4$ & 20,9 & 27,4 & 27,7 & 12,4 & 18,7 & 36,2 & 33,7 \\
\hline $\begin{array}{l}\text { Культури овочеві відкритого } \\
\text { грунту }\end{array}$ & 95,9 & 21,1 & 12,7 & 13,2 & 29,1 & 182 & 16,1 & 38,9 & 43 & 25,3 & 7,4 & $-88,5$ \\
\hline Картопля & 41,2 & 26,1 & $-39,3$ & 3,4 & 29 & 0,9 & $-7,9$ & 31,3 & 23,5 & $-1,1$ & 5,6 & $-35,6$ \\
\hline Культури плодові & - & - & - & - & 105 & - & - & - & $-6,9$ & $-2,2$ & 9 & - \\
\hline Культури ягідні & $-4,2$ & 6,3 & 5,4 & 74,1 & $-25,8$ & 222 & 109 & 88,3 & 50,1 & $-10,2$ & 29,1 & 33,3 \\
\hline Молоко & 15 & 23,6 & 3,2 & 15,8 & 11 & 15 & 21,2 & 19,5 & 5,9 & 3,2 & 8,2 & $-6,8$ \\
\hline Велика рогата худоба на м'ясо & $-36,4$ & $-19,1$ & $-27,2$ & $-38,8$ & $-30,7$ & $-15,5$ & $-18,1$ & $-3,8$ & $-7,5$ & $-12,7$ & -7 & 29,4 \\
\hline Свині на м’ясо & 10,8 & 18,7 & $-7,6$ & 7,3 & -1 & 50,4 & 33,9 & 10,7 & 3,2 & 17,7 & 25,7 & 14,9 \\
\hline Вівці та кози на м’ясо & $-45,6$ & -32 & $-53,4$ & $-71,6$ & - & - & - & - & -3 & $-23,4$ & - & - \\
\hline Птиця на м'ясо & 4 & 1,6 & $-0,4$ & 6,9 & $-5,2$ & $-5,7$ & $-1,2$ & 0,9 & 4,4 & 10,6 & 13,4 & 9,4 \\
\hline Яйця птиці свійської & $-5,5$ & $-16,7$ & 4,4 & 12,1 & 20,7 & 21,6 & 24,1 & 0,2 & 13,4 & 2,1 & 7,8 & 13,3 \\
\hline Вовна & - & - & - & - & - & - & - & - & - & - & - & - \\
\hline
\end{tabular}

*Джерело: розраховано на основі даних (Holovne upravlinnia statystyky..., 2021)

Руйнація соціальної інфрастуктури погіршує умови проживання, рівень життя сільського населення обмежує його в отриманні медичних, освітніх, побутових та інших послуг. Як відомо відновлення згаданої інфраструктури тісно пов'язано із наповненням місцевих бюджетів.

Отже, провідною метою покращення соціальноекономічного розвитку у сільській місцевості $є$ підвищення економічної ефективності використання ресурсів на окремо взятій сільській території. Сприятливим макро чинником для розвитку сільських територій $є$ процеси децентралізації, у т.ч. фінансової, в Україні. Зростання ваги місцевих громад, отримання ними права використання значної кількості ресурсів на своїй території може мати позитивний ефект лише за умов напрацювання програм розвитку підприємництва, залучення інвесторів.

Зростання надходжень до місцевих бюджетів збільшує можливості місцевих громад у реалізації ресурсного чи трудового потенціалу, вирішення своїх інфраструктурних потреб. У цьому контексті слід зазначити необхідність розробки місцевих програм розвитку території об'єднані територіальних громад.

Зазначені кошти можуть бути направлені на створення сприятливих умов для інвесторів, покращення стану об'єктів соціальної інфраструктури, придбання необхідної спеціалізованої техніки тощо.

Повертаючись до проблематики пожвавлення економічної активності регіону виділимо основні напрямки удосконалення роботи у сільськогосподарському виробництві.

Для Львівщини характерна велика концентрація агровиробництва в ОСГ проте як було зазначено вище ефективність використання ресурсів даною категорію $\epsilon$ невисока. Тому, на нашу думку, значну увагу слід надати розвитку багатофункціональності господарювання особистих селянських господарств за рахунок не лише сільськогосподарської діяльності. Провідни- ми напрямками підвищення економічного ефекту від діяльності ОСГ можуть бути наступні: об'єднання їх зусиль у формі кооперації, розвитку глибокої переробки продукції, несільськогосподарських видів діяльності (аграрний туризм, діяльність у сфері культури, виробництво енергії 3 відновлюваних джерел) (Hrabovskyi et al., 2018).

Згадані процеси диверсифікації активності господарств населення матимуть незаперечно великий $\mathrm{i}$ позитивний вплив для підняття рівня життя населення, скорочення відтоку трудових ресурсів. Приклади поширення практики несільськогосподарської діяльності на Львівщині можна побачити у гірських і передгірських районах області де активно розвивається сільський туризм.

У той же час розвиток сільськогосподарського виробництва $\epsilon$ пріоритетним напрямком економічної діяльності для агроформувань, фермерських господарств. Власне структура економічної діяльності різних категорій в окремо взятій територіальній одиниці напряму залежить від ï особливостей, наявності ресурсів. Проте $\epsilon$ чинники, які потрібно врахувати для максимального досягнення економічних показників від аграрної діяльності. Насамперед, це провадження сільськогосподарської діяльності з урахування земельних та природно-кліматичних регіону, застосування передових технологій 3 мінімальним впливом на навколишне природне середовище. Інтенсифікація сільськогосподарської діяльності тісно пов'язана із активним застосуванням наукових досягнень. Зокрема в рослинництві це використання районованих сортів зернових, технічних культур, підвищення продуктивності тваринництва, інтенсифікація кормовиробництва, ширшого застосування автоматизації процесів, відповідності якісних показників продукції вимогам ринку.

Підвищення економічних показників діяльності аграрних підприємств залежить від рівня забезпечен- 
ня матеріально-технічними ресурсами, використання виробничо-ресурсного потенціалу, інтеграції з переробними підприємствами та ОСГ.

У такому симбіозі особистих селянських господарств та сільськогосподарських підприємств можна досягнути максимального використання ресурсного потенціалу території та отримання можливостей для вирішення актуальних соціально-економічних проблем.

\section{Висновки}

За результатами дослідження встановлено, що виробництво сільськогосподарської продукції у особистих селянських господарств протягом останнього десятиліття перебуває приблизно на однаковому рівні без ознак росту. Натомість в агроформуваннях спостерігається ріст виробництва насамперед рослинницької продукції. Для ефективнішого використання ресурсів доцільно нарощувати їх в агроформуваннях, а у господарствах населення активно розвивати кооперацію, несільськогосподарські види діяльності. За умов збільшення можливостей використання коштів місцевими бюджетами в період децентралізації місцевим територіальним одиницям доцільно активно розвивати інфраструктуру, залучати інвесторів.

Перспективи подальших досліджень. Актуальними і перспективними напрямами подальших наукових досліджень даної тематики є напрацювання та економічна оцінка видів самозайнятості, підприємницької діяльності у сільській місцевості з урахуванням природно-кліматичних, демографічних, культурних та інших особливостей регіону, формування сприятливого інвестиційного клімату, розширення транскордонної співпраці, вивчення іноземного досвіду і можливостей застосування його у вітчизняних умовах.

\section{References}

Belei, S. I. (2021). Rozvytok silskykh terytorii v umovakh detsentralizatsii. Efektyvna ekonomika, 1, doi: 10.32702/2307-2105-2021.1.78 (in Ukrainian).

Boiko, V. V., Vasyltsiv, T. H., Voloshyn, V. I. Iliash, O. I., \& Lupak R. L. (2016). Napriamy ta zasoby rozvytku silskykh terytorii $\mathrm{v}$ konteksti zmitsnennia sotsialnoekonomichnoi bezpeky Ukrainy: monohrafiia. Lviv: Liha-Pres URL: http://ird.gov.ua/irdp/p20160804.pdf (data zvernennia: 20.10.2021) (in Ukrainian).

Borshchevskyi, V. V., Prytula, Kh. M., Krupin, V. Ye., \& Kulish, I. M. (2011). Problemy ta perspektyvy rozvytku silskykh terytorii Ukrainy (na prykladi Karpatskoho rehionu): naukovo-analitychna dopovid. NAN Ukrainy. Instytut rehionalnykh doslidzhen. Lviv. URL: https://ird.gov.ua/news/ndrt.pdf (data zvernennia: 20.10.2021) (in Ukrainian).

Holovne upravlinnia statystyky u Lvivskii oblasti. (2021). URL: https:/www.lv.ukrstat.gov.ua/ (in Ukrainian).

Hrabovskyi, R. S., Dudiak, R. P., Mahas, L. V., \& Dadak, O. O. (2018). Vyrobnytstvo ekolohichno chystoi produktsii ta rozvytok zelenoho turyzmu v Ukraini. Naukovyi visnyk LNUVMB imeni S.Z. Hzhytskoho. Seriia: Ekonomichni nauky, 20(91), 19-22. doi: 10.32718/nvlvet9104 (in Ukrainian).

Khomiuk, N. L., \& Pavlikha N. V. (2019). Metodychni pidkhody do analizu rozvytku silskykh terytorii $\mathrm{V}$ umova detsentralizatsii. Rehionalna ekonomika, 91(1), 47-55. doi: 10.36818/1562-0905-2019-1-6 (in Ukrainian).

Sabluk, P. T. (2005). Rozvytok silskykh terytorii v konteksti zabezpechennia ekonomichnoi stabilnosti derzhavy. Ekonomika APK, 11, 4-12 (in Ukrainian).

Talavyria, M. P., \& Horai, A. O. (2018). Rozvytok silskykh terytorii v umovakh detsentralizatsii. Ekonomika APK, 11, 75-79. doi: 10.32317/2221-1055.201811075 (in Ukrainian). 